WEST AFRICA

\section{SUBSCRIPTION QUERIES}

If you've got a query about your subscription, please write to the:

SALES AND DISTRIBUTION DEPARTMENT

WEST AFRICA

PUBLISHING CO. LTD.

43-45 COLDHARBOUR LANE CAMBERWELL LONDON SE5 9NR ENGLAND

Telephone No: 071-737 2946

Fax: 071-978 8334

Telex: 892420 WESTAF-G

We'll be able to sort out your query more quickly if you give us your

Subscription Number

beginning with WA

(this is above your name and address on the envelope used in sending your magazine)

\section{CHANGE OF ADDRESS}

If you're changing your address, please send us the envelope that came with your latest copy of WEST AFRICA

\section{OVER 100,000 READERS}

RELY ON WEST AFRICA MAGAZINE EVERY WEEK

Published weekly since 1917

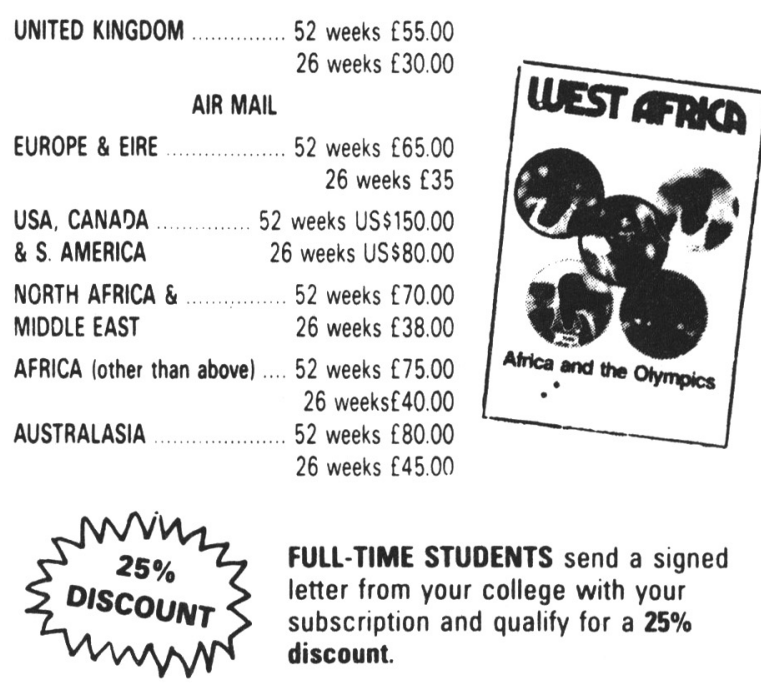

\section{Subscription Order Form}

$\square$ I enclose cheque/Sterling Postal Order (UK).

$\square$ International Postal Order/Money Order (Overseas) for $6 / 12$ months subscription Air Mail. Delete as applicable.

Cheque/Money Order made payable to West Africa Publishing Co Ltd. OR

Charge my credit card

$\square$ Visa/Barclaycard
$\square$ Mastercard/Access

Please allow 14 days to process your order Card No

Card Expiry date. Signature

Name

Address

Credit Card Address (if different from above)

Please return to: Subscriptions Department WEST AFRICA PUBLISHING CO LTD 43-45 Coldharbour Lane, Camberwell London SE5 9NR

Telephone: 071-737 2946

Telex: 892420 WEST AF-G Fax: $071-9788334$ 


\section{MEMBERSHIP \\ AFRICAN STUDIES ASSOCIATION}

Demographic information is for statistical purposes only and will not be included in the 1994 ASA Membership Directory. If you do not wish to be included in the membership direectory, please check here.

Name

If Joint Member, second name

Address

City State Zip Code Country

Institutional Affiliation If retired, yr of retirement

Title Office or Home phone

Occupation

Email address Fax

Last degree rec'd Year rec'd Institution

Language(s) spoken or written Country of Citizenship

Ethnicity (please circle) Asian White Black Hispanic Other

Gender Date of birth Country of birth

Discipline (please circle) Anthropology

Arts

Economics

Education

Geography

History

Library Science

Literature

Language/Linguistics/Communication

Political Science/Int'l Relations

Religious Studies

Sociology

Other
Regional interest (please list country/countries within each region)

North Africa

East Africa

Central Africa

West Africa

Southern Africa

\section{DUES}

Regular

Income over $\$ 60,000$

Income from $\$ 45-\$ 60,000$

Income from $\$ 30-\$ 45,000$

Income from $\$ 15-\$ 30,000$

Income below $\$ 15,000$

Joint

(Second person in household with one regular member)

Airmail

(Optional for persons resident outside North America)

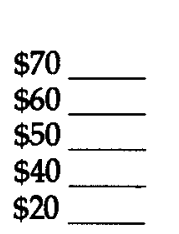

Lifetime

One-time payment of $\$ 1200$

(or 3 annual installments of $\$ 400$ )

One-year subscription to the Canadian Journal of

African Studies (available with ASA membership at this special price)

$\$ 40$

$\$ 20$ Endowment Contribution

I am enclosing a matching gift to the

ASA Challenge Grant Campaign in the amount of

TOTAL AMOUNT ENCLOSED

No separate confirmation of membership will be sent to you before you receive membership mailings.

Please pay by check or money order. Members residing outside the US must send a money order, a check in US dollars drawn on a US bank, or a UNESCO coupon as payment. 


\section{History in Africa \\ A JOURNAL OF METHOD}

Published annually since 1974

Focuses on historiographical and methodological concerns:

- textual analysis and criticism

- historiographical essays

- the role of nonhistorical data in historical reconstruction

- the role of theory in historical investigation

- bibliographical essays

- archival reports

\section{EDITORIAL CORRESPONDENCE}

Manuscripts and other editorial correspondence should be directed to David Henige, Memorial Library, University of Wisconsin, Madison WI 53706. Phone 608-262-6397.

\section{SUBSCRIPTION INFORMATION}

History in Africa (ISSN 0361-5413) is published annually by the African Studies Association. For subscriptions and back issues, write: African Studies Association, Credit Union Building, Emory University, Atlanta GA 30322 USA. Phone 404-329-6410. FAX 404-329-6433.

Mail to: $\quad$ History in Africa African Studies Association Credit Union Building Atlanta GA 30322 USA
Institutions in USA

Institutions outside USA

Air mail outside USA Individuals in USA

Individuals outside USA
$\$ 40.00$

$\$ 42.00$

$\$ 45.00$

$\$ 25.00$

$\$ 27.00$

Please enter my subscription to History in Africa. Amount enclosed: US\$

Name

Address

Gity

State

Zip Country 

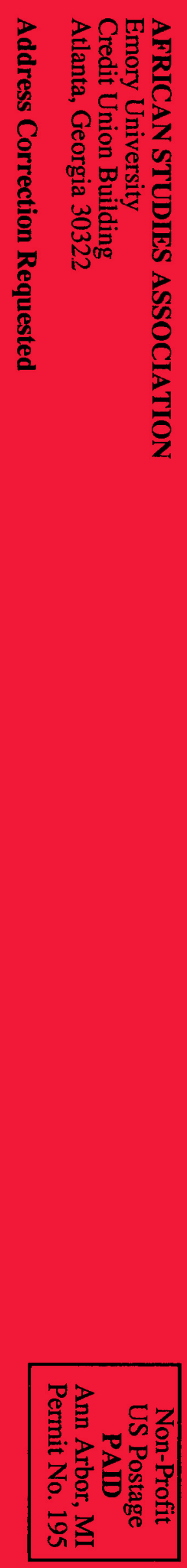

Published online by Cambridge University Press 